Article

\title{
An Index of Aquiclude Destabilization for Mining-Induced Roof Water Inrush Forecasting: A Case Study
}

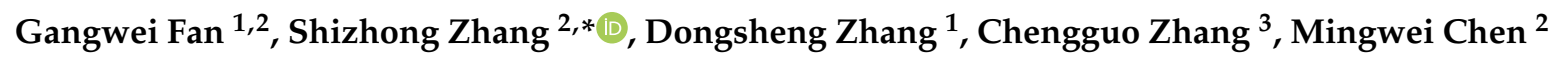 \\ and Qizhen $\mathrm{Li}^{2}$ \\ 1 State Key Laboratory of Coal Resources and Safe Mining, China University of Mining \& Technology, \\ Xuzhou 221116, China; fangangwei@cumt.edu.cn (G.F.); dshzhang123@cumt.edu.cn (D.Z.) \\ 2 School of Mines, China University of Mining \& Technology, Xuzhou 221116, China; \\ mingwei@cumt.edu.cn (M.C.); lqz3533@cumt.edu.cn (Q.L.) \\ 3 School of Mining Engineering, University of New South Wales, Sydney 2052, Australia; \\ chengguo.zhang@unsw.edu.au \\ * Correspondence: zhangshizhong@cumt.edu.cn; Tel.: +86-183-6126-2484
}

Received: 6 September 2019; Accepted: 16 October 2019; Published: 18 October 2019

\begin{abstract}
Aquiclude plays a critical role in the occurrence of mining-induced roof water inrush in underground coal mines. This paper proposes an assessment index for the evaluation of aquiclude stability and a threshold value of water inrush from the roof, based on a case study of roof water inrush accidents in Cuimu coal mine, China. The relation between roof water inrush and water level variation in the aquifer, and the characteristics of aquiclude deformation, were studied in this assessment. Using the developed assessment criteria, the likelihood of roof water inrush was categorized into different risk levels, which were followed by a proposal for roof water inrush control measures. The main findings of this study are: a) in Cuimu coal mine, the waterbody in the bed separation between the upper aquifer and the aquiclude directly causes the inrush, and inrush occurs after the water level declines in the aquifer; $b$ ) tension-induced horizontal strains of aquiclude can be regarded as the index to evaluate the stability of aquiclude affected by underground coal mining-roof water inrush occurs when the maximum horizontal strain reaches a threshold of $10 \mathrm{~mm} / \mathrm{m}-\mathrm{c}$ ) based on the critical mining height for aquiclude instability, and the different thicknesses of barrier layers, high-risk zones are identified and inrush controls are proposed.
\end{abstract}

Keywords: aquiclude stability; roof water inrush; threshold value; horizontal strain; critical mining height

\section{Introduction}

Mine roof water inrush has been identified as one of the most critical threats to mining safety and production in China. With characteristics such as burstiness, instantaneity and destructiveness, water inrush can trigger various degrees of catastrophe, ranging from submerging the working face, to mine flooding and casualties. These accidents have resulted in tremendous losses to workforce safety and state economy [1,2]. Currently, mine water inrush is affected by a range of factors, including hydraulic pressure, water yield of the aquifer, effective thickness, thickness of resistance rock strata, as well as geological structure (fault and collapse columns) [3-8]. As a major protective layer below the aquifer, aquiclude plays an important role in controlling roof water inrush, due to its waterproof function. Generally, coal extraction can result in overburden strata deformation, breakage and collapse, accompanied by mining-induced fractures, developing upwards. After being penetrated by fractures, aquiclude may lose its waterproof efficacy, because its natural stability has deteriorated [9]. Water can 
flow from the aquifer into working areas along with widespread fractures, which then results in mine roof water inrush. Therefore, using a case study, this paper assesses the roof water inrush risks of each working area, through analyzing the variation of aquiclude stability during underground mining. This is of great significance for water disaster prevention and control in coal mines.

There has been a large amount of research on mining-induced water inrush. To date, these works mainly focus on the mechanisms of water inrush, vulnerability assessment, water inrush prediction and control methods, etc. [10-13]. For instance, Donnelly and Islam et al. found that fault reactivation caused by stress redistribution from mining can cause groundwater inrushes, because of the combined action of seepage and stress [14,15]. Zhang et al. and Yin et al. suggested that the main inducers of water inrush were mining-induced water-flowing fractures and hydraulic fractures caused by water pressure in the aquifer $[16,17]$. Moreover, water inrush was mostly related to fault structure. Based on mathematical methods, like geographic information system (GIS) and the analytic hierarchy process (AHP), Wu et al. evaluated the water inrush vulnerability of the overlying aquifer [18]. For areas at risk of water inrush, blockage by grouting in working face, and dewatering the aquifer ahead of working face, could be used to lower the risk of water inrush. In addition, Wang and Park and Klose suggested that mining activities could cause a significant increase in groundwater inrushes into mines from aquifers, through natural or mining-related fractured zones [19,20]. Yin et al. and Zhou et al. found that mine water inrush was related to fault activation, caused by mining. Mining activities made the fault hydraulically conductive and connected to the aquifer [21,22]. Zhang and Yang obtained the qualitative and quantitative indicators of the roof water inrush prediction model in shallow seam mining by using a combined method of analytic hierarchy process (AHP) and grey relational analysis (GRA) [23]. Hu et al. obtained a critical roof water inrush criterion, based on the principle of minimum potential energy and Mohr-Coulomb yield criterion, in which the linear increase in water pressure and the supporting force of fractured rock mass were considered [24].

Situ measurements and theoretical analyses have been carried out to study the characteristics of aquiclude destabilization and failure. Based on the results of field monitoring, Adhikary and Guo found that coal extraction could change the pore pressure, permeability, and water inflow of overlying strata, and then affect the waterproof performance of rock mass [25]. Booht et al. and Zhang et al. revealed that the aquiclude could remain steady to some extent, so that the declined water level in the inner aquifer could be regained, based on a sequence of field measurements [26-28]. However, this was based on the assumption that the aquiclude had not been devasted by underground exploitation. Adams and Younger and Majdi et al. suggested that the water-flowing fractured zone will form in the overburden, along with the mining activities. When the fractured zone reaches, or goes through, the overlying aquiclude, the water contained in the aquifer will most likely flow into the mined-out area. Based on a mathematical approach, an empirical formula of mining thickness and the maximum height of the water-flowing fractured zone, was proposed [29,30].

Previous research in the area of mine water inrush mainly focuses on the inrush mechanism, risk assessment and prediction, prevention and control methods, as well as the generic mechanism of aquiclude destabilization and failure. An index and/or threshold value, in order to assess the stability of the aquiclude when water inrush occurs in coal mines, is important when predicting roof water inrush, and there has not been an effective value proposed in the literature. Therefore, on the basis of roof water inrush events in Cuimu coal mine in Shanxi, China, numerical simulation and analysis are conducted in this paper, using the Universal Distinct Element Code (UDEC), to assess the characteristics of aquiclude deformation and failure. Through comprehensive parametric analysis, the connection between aquiclude stability and roof water inrush is identified, followed by a proposal for roof water inrush control measures. The outcomes of this paper can offer insight into, and guidelines for, roof water inrush assessment and controls. 


\section{Index of Aquiclude Stability}

Based on the geological conditions of Cuimu coal mine and the event of roof water inrush, the mechanisms of roof water inrush in the working face are analyzed in this section. Numerical simulation, to investigate the evolution law of aquiclude stability affected by underground mining, is conducted using UDEC. On this basis, the evaluation index and threshold value are confirmed. Both of these aspects are of great importance when assessing the stability of aquiclude influenced by mining, relating to mine roof water inrush.

\subsection{Geological Conditions of Cuimu Coal Mine}

The 3\# coal seam situated in the Jurassic stratum is primarily extracted with a depth of $576.9-600.0 \mathrm{~m}$ at Cuimu coal mine. With a dip angle of 3 to 6 degrees, $3 \#$ coal seam is divided into two longwall panel series, as 21 and 22. The working face 21301 in panel group 21 is retreated first. Full-mechanized caving method is utilized to extract the coal seam, with an average seam thickness of $16 \mathrm{~m}$ in 21301, and $12 \mathrm{~m}$ in 21302. Overburden strata of 3\# coal mine are composed of mudstone and sandstone. The mudstone formation (mudstone and sandy mudstone) serves as the key aquiclude. The rock mass in the mudstone formation is weak, but has a stable performance in water-resisting. In the Cretaceous stratum, there is a key aquifer with high strength and abundant water, which is mainly composed of coarse sandstone and medium sandstone. The uniaxial compressive strength of coarse sandstone and medium sandstone in the aquifer is 17.2-26.2 MPa, with an average of $21.7 \mathrm{MPa}$, while the uniaxial compressive strength of mudstone aquiclude is only 7.4 MPa. In addition, the unit inflow and permeability coefficient of aquifer from the Cretaceous stratum are $0.2 \mathrm{~L} /(\mathrm{s} \cdot \mathrm{m})$ and $0.1425 \mathrm{~m} / \mathrm{d}$, respectively. The average parting distance between the roof of the two working faces and the key aquifer is around $170 \mathrm{~m}$. Geologic stratigraphic information of the two panels is shown in Figure 1.

\begin{tabular}{|c|c|c|c|c|}
\hline STRATUM & COLUMN & LITHOLOGY & THICKNESS & REMARK \\
\hline \multirow{4}{*}{$\begin{array}{l}\text { Cretaceous } \\
\text { (K11) }\end{array}$} & & Gritstone & $96.1 \mathrm{~m}$ & \multirow{2}{*}{$\begin{array}{c}\text { Aquifer } \\
\text { (Hard rock) }\end{array}$} \\
\hline & & Medium sandstone & $12.1 \mathrm{~m}$ & \\
\hline & & Sandy mudstone & $5.8 \mathrm{~m}$ & \multirow{2}{*}{$\begin{array}{l}\text { Aquiclude } \\
\text { (Soft rock) }\end{array}$} \\
\hline & $\therefore$ & Sandy mudstone & $14.8 \mathrm{~m}$ & \\
\hline Jurassic $(\mathbf{J} 2 \mathrm{a})$ & & Sandy mudstone & $77.8 \mathrm{~m}$ & \multirow{5}{*}{$\begin{array}{l}\text { Aquiclude } \\
\text { (Soft rock) }\end{array}$} \\
\hline \multirow{5}{*}{ Jurassic $(\mathbf{J} 2 \mathrm{Z})$} & & Mudstone & $17.4 \mathrm{~m}$ & \\
\hline & & Coarse sandstone & $14.7 \mathrm{~m}$ & \\
\hline & & Mudstone & $13.9 \mathrm{~m}$ & \\
\hline & & Sandy mudstone & $19.3 \mathrm{~m}$ & \\
\hline & 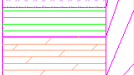 & Coarse sandstone & $8.0 \mathrm{~m}$ & $\begin{array}{c}\text { Immediate } \\
\text { roof }\end{array}$ \\
\hline Jurassic (J2y) & 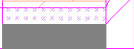 & 3\# Coal seam & $12 \mathrm{~m}$ & Coal seam \\
\hline
\end{tabular}

Figure 1. Stratigraphic column of 21301 and 21302 working faces.

\subsection{Case Study on Roof Water Inrush in Working Face}

To monitor the variation of water levels in the key aquifer, as well as the development height of the water flowing fractured zone in overburden strata, five prospect boreholes from G1 to G5 are set up in three working faces. The ultimate position of the G1 and G3 is at the bottom of K11. Their depths are $351.2 \mathrm{~m}$ and $302.8 \mathrm{~m}$, respectively. Detailed locations of each borehole are shown in Figure 2. 


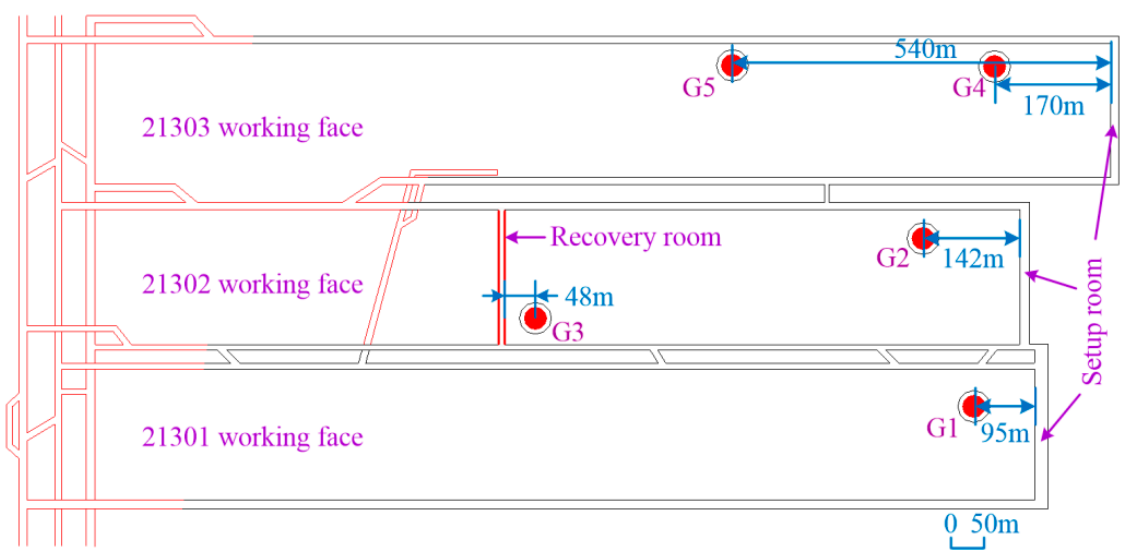

Figure 2. Sketch map for the location of prospect boreholes.

Since coal seam extraction, there have been 12 and four roof water inrush events, occurring in panels 21301 and 21302, respectively. Instantaneous maximum water inflow greater than $60 \mathrm{~m}^{3} / \mathrm{h}$ was recorded, as shown in Figure 3. According to the monitoring results from G1 and G3 boreholes, roof water inrush occurred when the retreat distance was $750 \mathrm{~m}$ for 21301, and $200 \mathrm{~m}$ for 21302 . Variations of water level in G1 and G3 boreholes are plotted before and after roof water inrush, in Figure 4.

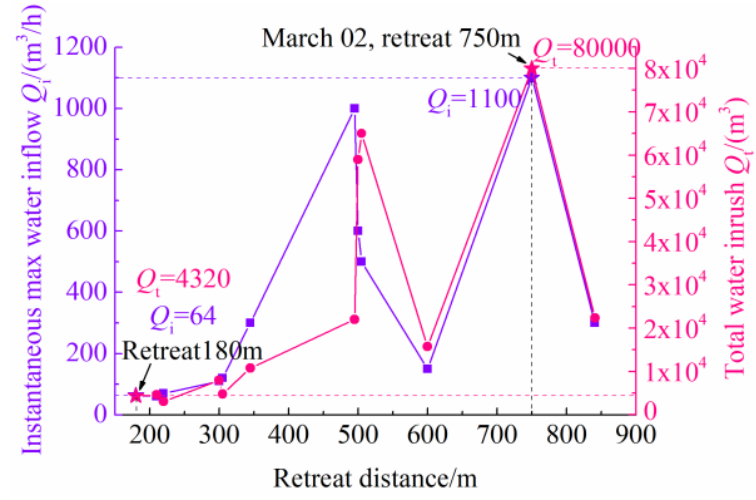

(a)

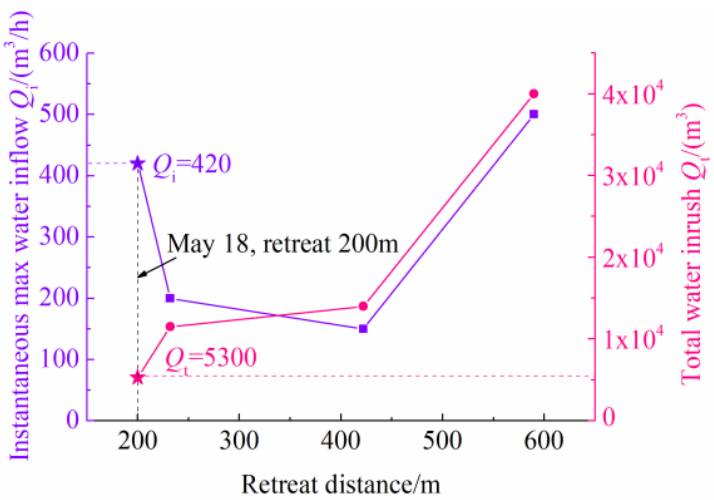

(b)

Figure 3. Statistics of roof water inrush in two working faces (instantaneous maximum water inflow more than $60 \mathrm{~m}^{3} / \mathrm{h}$ ): (a) 21301 working face; (b) 21302 working face.

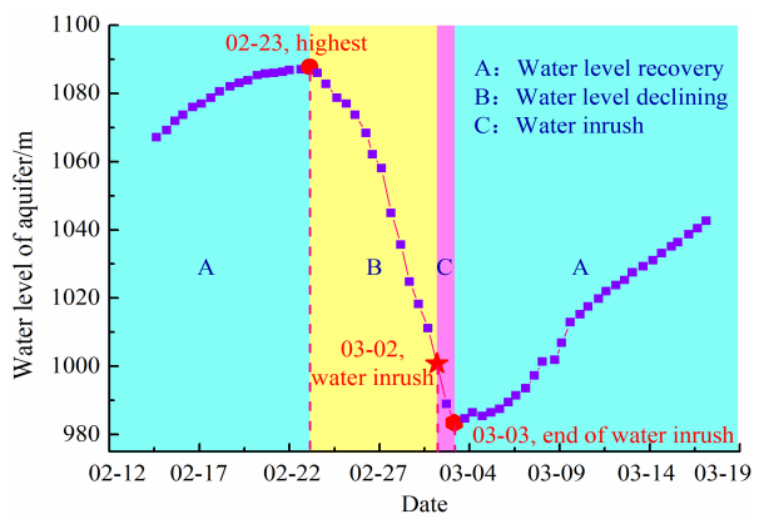

(a)

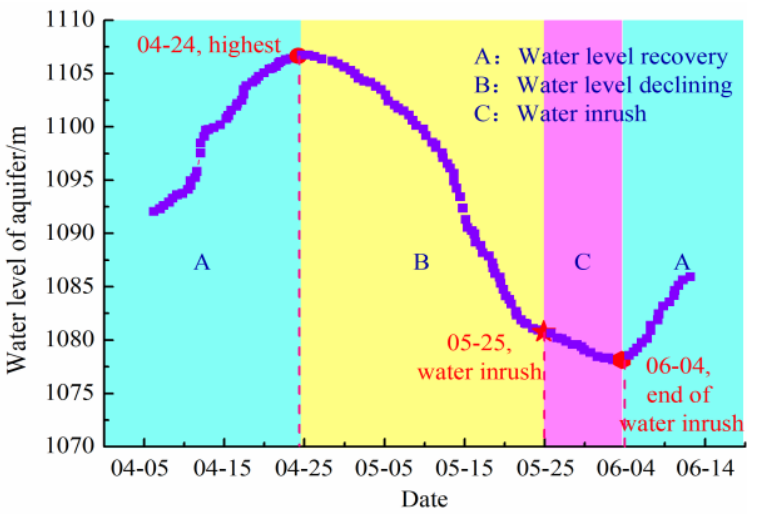

(b)

Figure 4. Water level variation in aquifer around the roof water inrush: (a) 21302 working face (1 March); (b) 21302 working face (18 May). 
Figure 3a shows that a roof water inrush accident occurred at 21301, when the retreat distance reached $750 \mathrm{~m}$, on 2 March. The instantaneous maximum water inflow Qi reached $1100 \mathrm{~m}^{3} / \mathrm{h}$, compared to the total water inflow Qt, with a rate of $80,000 \mathrm{~m}^{3}$. According to Figure $4 \mathrm{a}$, the water level of the aquifer had declined by $104 \mathrm{~m}$, one week before roof water inrush. Figure $3 \mathrm{~b}$ indicates that a water inrush event occurred in 21302, when the retreat distance reached $200 \mathrm{~m}$ on 18 May. Similarly, Figure $4 \mathrm{~b}$ shows a continuous decline in the water level of aquifer before roof water inrush. These phenomena indicate that roof water inrush is preceded by a decline in water level.

The case study of Cuimu roof water inrush indicates that there might be a large-scale space between the aquifer and the lower aquiclude prior to the roof water inrush occurrences, which can reserve great masses of water, causing the water level of the aquifer to gradually decline. At this moment, the aquiclude still has a certain waterproof capacity, as mining-induced fractures have not passed through the aquiclude. As the longwall retreat continues, fractures keep developing, extending upwards towards the aquiclude. Ultimately, along with widespread fractures in the aquiclude, upper water could be discharged from the aquifer and flow into lower panel areas, triggering mine roof water inrush. Generally, roof water inrush occurs after a decline in water level in the aquifer.

\subsection{Analysis of Inrush Mechanism and Threshold Determination}

UDEC numerical modelling was conducted to study the characteristics of the void, relating to water storage between the aquifer and the aquiclude before roof water inrush, its location, and the specific mechanism of roof water inrush in this condition.

\subsubsection{Mechanisms of Roof Water Inrush}

The distribution of the plastic zone, and characteristics of overburden strata movement, with 21301 and 21302 working faces at different retreat distances, are shown in Figure 5.

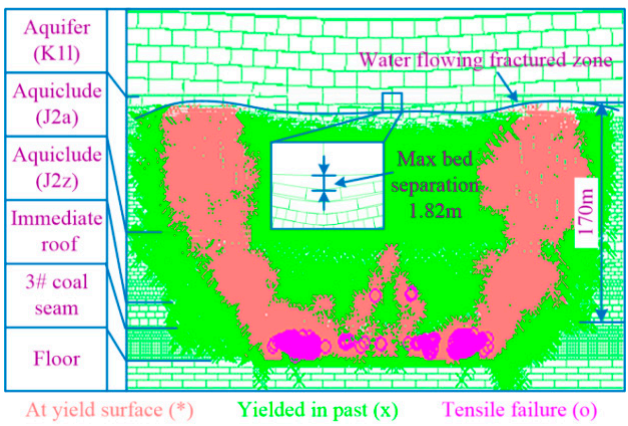

(a)

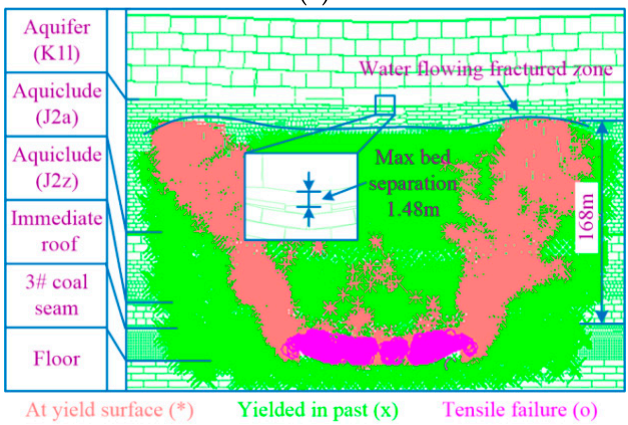

(c)

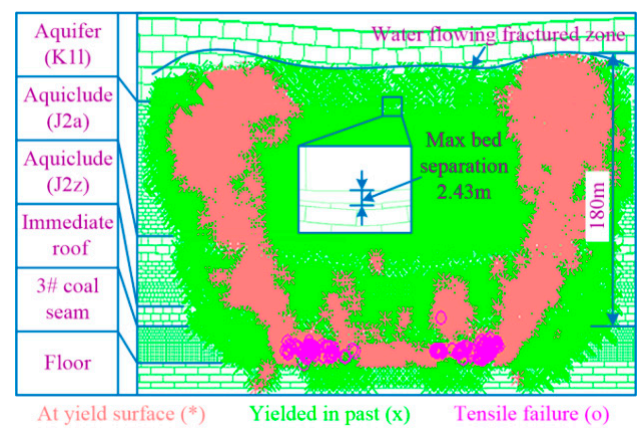

(b)

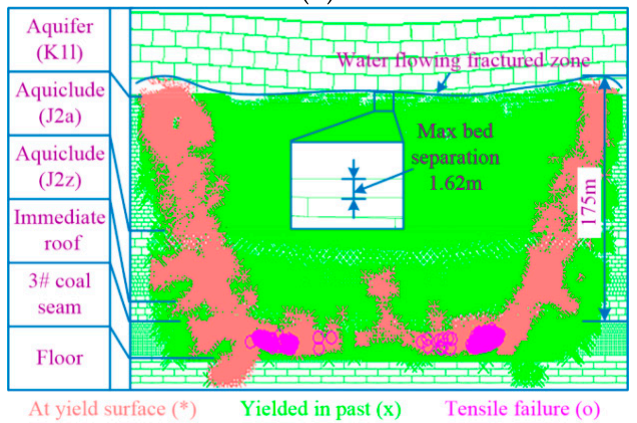

(d)

Figure 5. Distribution of plastic zone and characteristics of strata movement at different retreat distances: (a) 21301 working face (retreat $160 \mathrm{~m}$-no water inrush); (b) 21301 working face (retreat $180 \mathrm{~m}$-water inrush); (c) 21302 working face (retreat $180 \mathrm{~m}$-no water inrush); (d) 21302 working face (retreat $200 \mathrm{~m}$-water inrush). 
According to Figure 5a,b, when the 21301 working face retreated $160 \mathrm{~m}$, the fractured zone nearly reached the top of the aquiclude, and kept at a distance of $2 \mathrm{~m}$ from the bottom of the aquifer. Two formations are divided by a bed separation, with a height of $1.82 \mathrm{~m}$. When the 21301 working face retreated $180 \mathrm{~m}$, the water flowing fractured zone extended to the aquifer for the first time and overtopped the bottom of the aquifer, at a distance of $8 \mathrm{~m}$. During this period, bed separation increased to $2.43 \mathrm{~m}$ in height. During actual mining operation, the water level of the aquifer declined without water inrush, when the 21301 working face retreated $160 \mathrm{~m}$. The first roof water inrush occurred following a retreat of $180 \mathrm{~m}$. The modeling results are in accordance with actual cases.

As shown in Figure 5c,d, when the retreat distance is $180 \mathrm{~m}$, the water flowing fractured zone is situated in the aquiclude and keeps a distance of $4 \mathrm{~m}$ from the bottom of the aquifer. The maximum height of bed separation between the aquiclude and aquifer is $1.48 \mathrm{~m}$. As the working face moves $20 \mathrm{~m}$ forwards, water flowing fractures interact with the aquifer and overtop the bottom of the aquifer by $3 \mathrm{~m}$. Bed separation has a sequential growth of $1.62 \mathrm{~m}$. Similarly to the 21301 panel, the results of numerical modelling of the 21302 working face accord with actual roof water inrush cases.

Therefore, it is the bed separation between the aquifer and aquiclude that provides a large-scale space to store water, so the phenomenon associated with water level decline in aquifer can be observed in advance. During this period, aquiclude still has a good waterproof capacity, because the water flowing fractures have not contacted the aquifer, so roof water inrush cannot occur. Further coal extraction makes the area of bed separation increasingly large, so it can contain more water derived from the upper aquifer. Then, this part of the water flows into the underground working face and results in roof water inrush, once mining-induced fractures occur throughout the entire aquiclude. The above analyses indicate that the water from the aquifer can be temporarily accumulated and stored in the space generated by bed separation between the aquifer and aquiclude, and then flow into the deeper working face. This may be the reason there is a time lag for roof water inrush, which occurs after a water level decline in the aquifer.

\subsubsection{Stability Index of Aquiclude}

Results of numerical modelling indicate that aquiclude, affected by underground coal mining, tends to bend and fail, because it is mainly composed of soft rocks. According to the work done by Zhang et al. [9], V-type fractures in aquiclude may form and extend to the top of the aquiclude, under the influence of horizontal tension. The waterproof capacity of the aquiclude will be diminished once it has passed through the V-type fractures. At the same time, by comparing vertical displacement, horizontal displacement, curvature and horizontal strain, it was found that the horizontal strain could intuitively reflect the opening and closing of water flowing fractures, and inrush channels of aquiclude [31-33]. Therefore, horizontal strain was selected as a key index for assessing aquiclude stability.

\subsubsection{Threshold Value of Roof Water Inrush}

As the numerical models in UDEC agree with actual roof water inrush cases, the threshold value of mine roof water inrush is determined using the modelling results. On that basis, a horizontal measuring line is set up in the center of J2a aquiclude to investigate the characteristics of aquiclude deformation during mining. The center position is close to the neutral layer of J2a aquiclude, which is neither pulled nor pressed during the bending process. For both working faces, detailed horizontal strains of aquiclude, with coal extraction taking place, can be shown in Figure 6.

Figure 6a shows the horizontal strain caused by tension peaks at $9.2 \mathrm{~mm} / \mathrm{m}$, when the 21301 working face retreated $160 \mathrm{~m}$. At that time, according to the field monitoring analysis, as shown in Figures 3a and 4a, roof water inrush has not occurred, although there is a decline in the water level of the aquifer. Roof water inrush occurs as the working face continuously retreats $180 \mathrm{~m}$, with a maximum horizontal strain of $13 \mathrm{~mm} / \mathrm{m}$. Comparison of the situation before and after roof water inrush indicates that the horizontal strain of the aquiclude should be greater than $9.2 \mathrm{~mm} / \mathrm{m}$ when roof water inrush happens to the 21301 working face. 


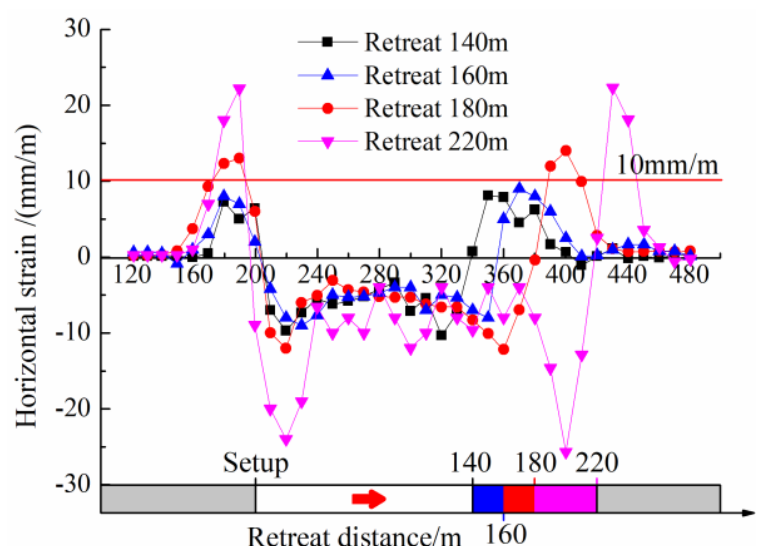

(a)

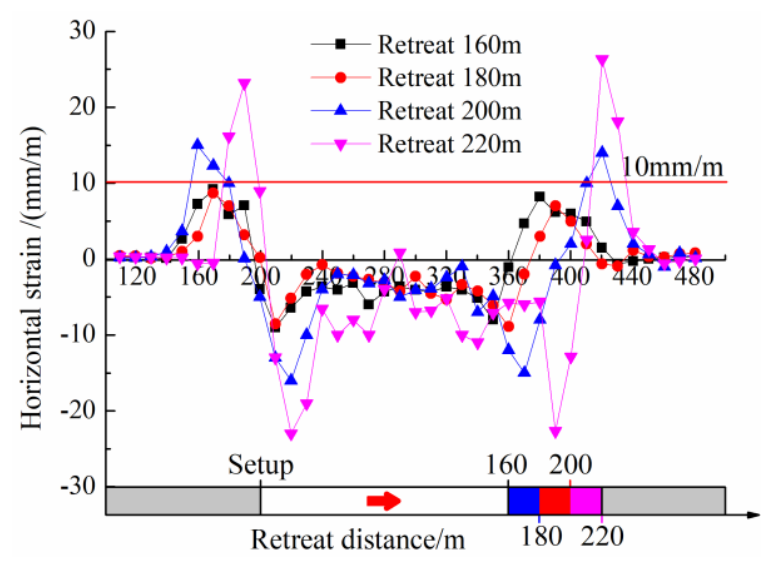

(b)

Figure 6. Horizontal strain of aquiclude at different retreat distances: (a) 21301 working face; (b) 21302 working face.

The same analysis procedure as above is utilized to investigate the situation of 21302 working face. Combining Figure $6 \mathrm{~b}$ with Figure $5 \mathrm{c}, \mathrm{d}$, the horizontal strain of the aquiclude reaches maximum value at the rate of $8.7 \mathrm{~mm} / \mathrm{m}$, when 21302 working face has retreated $180 \mathrm{~m}$. Although the water level of the aquiclude declines, inrush phenomenon has not appeared, because there is still distance between the water flowing fractured zone and upper aquiclude. Another roof water inrush occurs in 21302 panel at a $200 \mathrm{~m}$ retreat distance, and the maximum horizontal strain of the aquiclude is $15 \mathrm{~mm} / \mathrm{m}$. Similarly, simulation consequence indicates that the horizontal strain of the aquiclude should be greater than $8.7 \mathrm{~mm} / \mathrm{m}$ when roof water inrush happens in 21302 working face.

Therefore, based on the above analysis of simulation results and field roof water inrush cases, horizontal strain with a rate of $10 \mathrm{~mm} / \mathrm{m}$ can be regarded as the threshold value of aquiclude destabilization for roof water inrush.

\section{Water Inrush Risk Classification}

\subsection{Modelling Design}

Based on the threshold value of roof water inrush and the geological model of panel 21 in Cuimu coal mine (in Figure 7), underground areas at risk of roof water inrush can be identified and categorized. Barrier layer is defined as the rock strata from the top of the coal seam up to the bottom of the aquifer. This part of the strata has waterproof functions, to block off inrush water flowing from the top down. 25 UDEC numerical models are established, to analyze horizontal strains of the aquiclude at different thicknesses of barrier layer and different mining heights. Detailed numerical model setups are shown in Table 1.

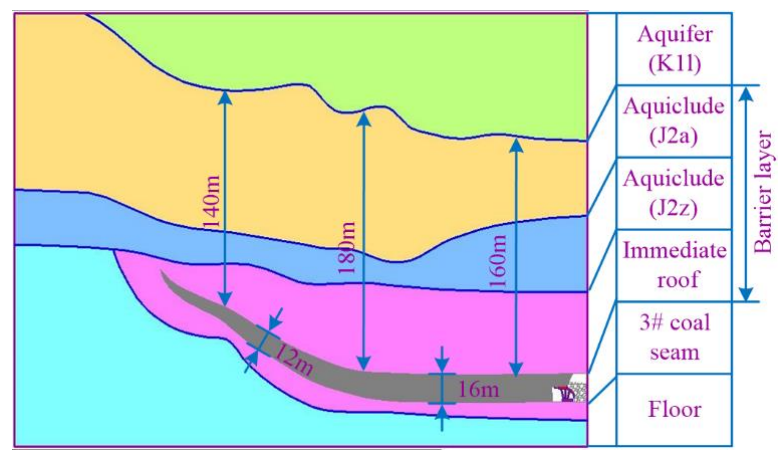

Figure 7. Geological model of panel 21 in Cuimu coal mine. 
Table 1. Scheme of numerical models.

\begin{tabular}{cccccc}
\hline Thickness of Barrier Layer/m & \multicolumn{5}{c}{ Height of Mining/m } \\
\hline 140 & 10 & 12 & 14 & 16 & 18 \\
150 & 10 & 12 & 14 & 16 & 18 \\
160 & 10 & 12 & 14 & 16 & 18 \\
170 & 10 & 12 & 14 & 16 & 18 \\
180 & 10 & 12 & 14 & 16 & 18 \\
\hline
\end{tabular}

\subsection{Critical Mining Conditions of Aquiclude Destabilization}

A horizontal strain of the aquiclude with different thicknesses of barrier layer can be acquired through numerical modelling, as shown in Figure 8. The maximum horizontal strain of the aquiclude is $8 \mathrm{~mm} / \mathrm{m}, 17 \mathrm{~mm} / \mathrm{m}, 18 \mathrm{~mm} / \mathrm{m}, 35 \mathrm{~mm} / \mathrm{m}$ and $40 \mathrm{~mm} / \mathrm{m}$, respectively, with a barrier thickness of $140 \mathrm{~m}$, and mining heights of $8 \mathrm{~m}, 10 \mathrm{~m}, 12 \mathrm{~m}, 14 \mathrm{~m}$ and $16 \mathrm{~m}$. When the mining height is $8 \mathrm{~m}$, the aquiclude can remain stable, with a maximum horizontal strain of the aquiclude less than $10 \mathrm{~mm} / \mathrm{m}$ after completion of the panel. Similarly, with barrier thicknesses of $150 \mathrm{~m}, 160 \mathrm{~m}, 170 \mathrm{~m}$ and $180 \mathrm{~m}$, the critical mining heights that can make the aquiclude destabilized are $10 \mathrm{~m}, 12 \mathrm{~m}, 12 \mathrm{~m}$ and $14 \mathrm{~m}$ respectively.

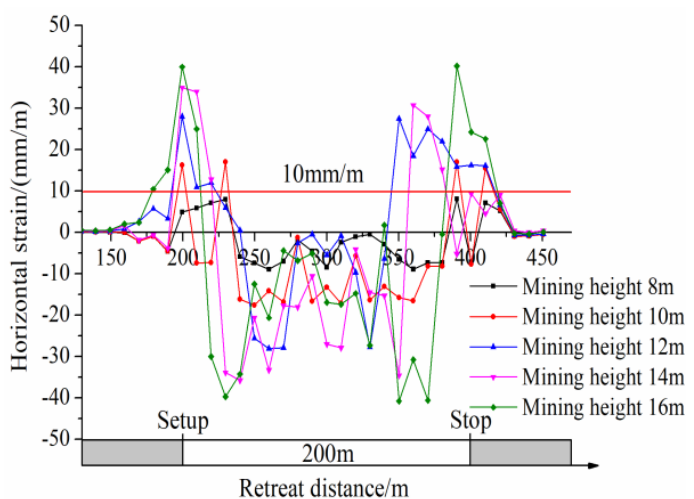

(a)

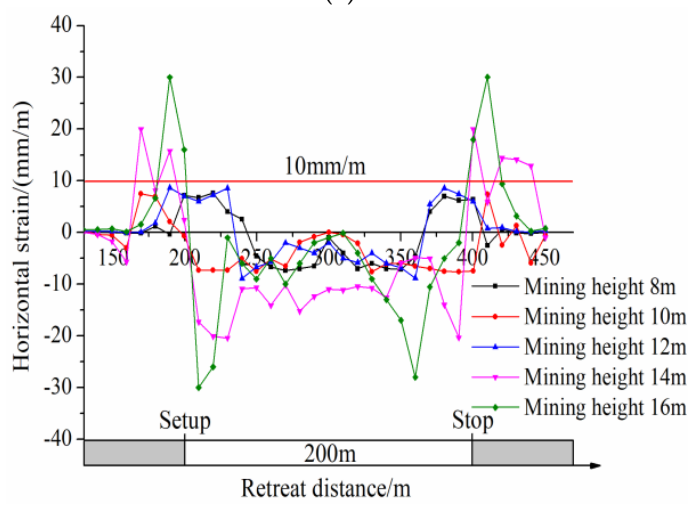

(c)

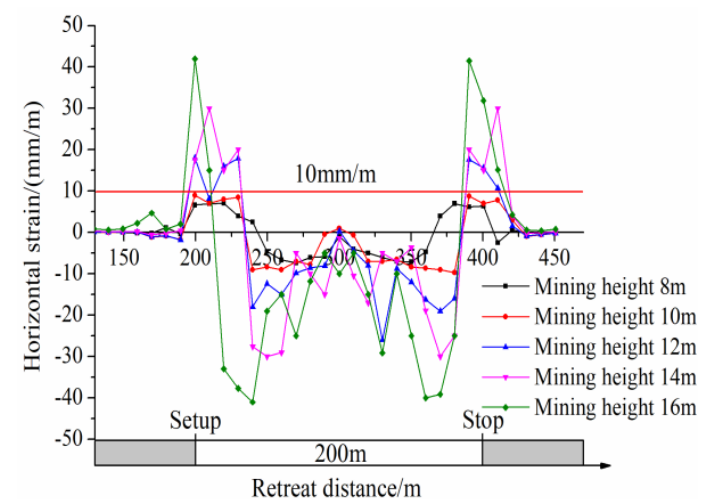

(b)

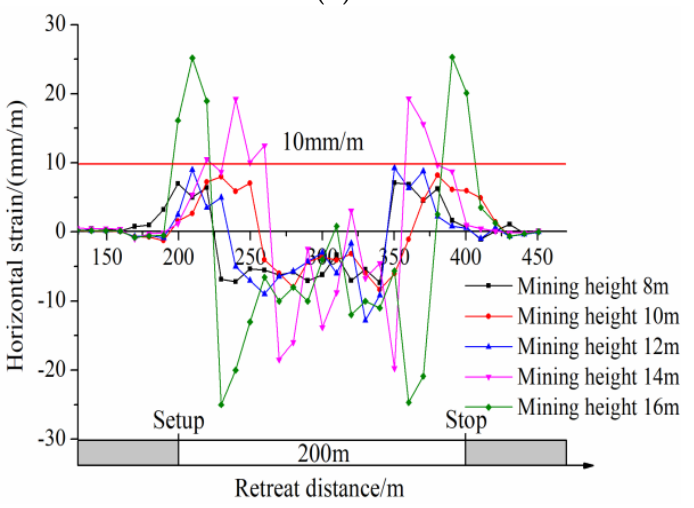

(d)

Figure 8. Cont. 


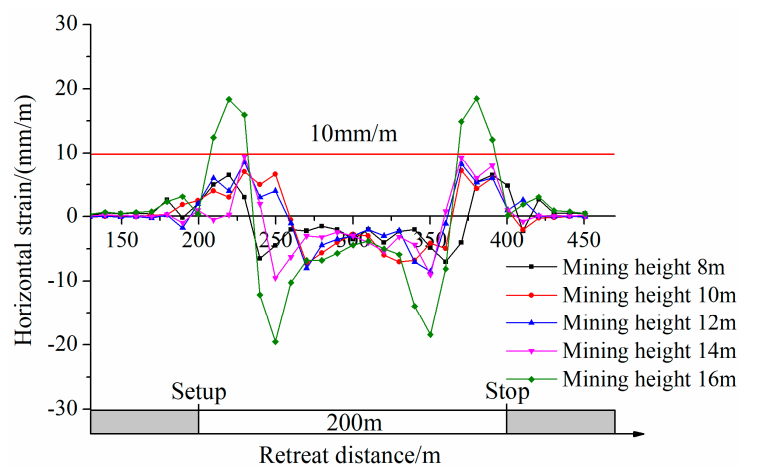

(e)

Figure 8. Horizontal strain of aquiclude with different thickness of barrier: (a) Barrier thickness $140 \mathrm{~m}$; (b) Barrier thickness-150 m; (c) Barrier thickness-160 m; (d) Barrier thickness-170 m; (e) Barrier thickness-180 m.

Based on numerical modelling results, Figure 9 shows horizontal strains of the aquiclude under different conditions of mining height. It reveals that maximum horizontal strains are less than $10 \mathrm{~mm} / \mathrm{m}$ when mining height is $8 \mathrm{~m}$, and the aquiclude has not destabilized at this moment. As mining height increases from $10 \mathrm{~m}$ to $12 \mathrm{~m}, 14 \mathrm{~m}$ and $16 \mathrm{~m}$, critical barrier thicknesses are $10 \mathrm{~m}, 12 \mathrm{~m}, 12 \mathrm{~m}$ and $14 \mathrm{~m}$ respectively.

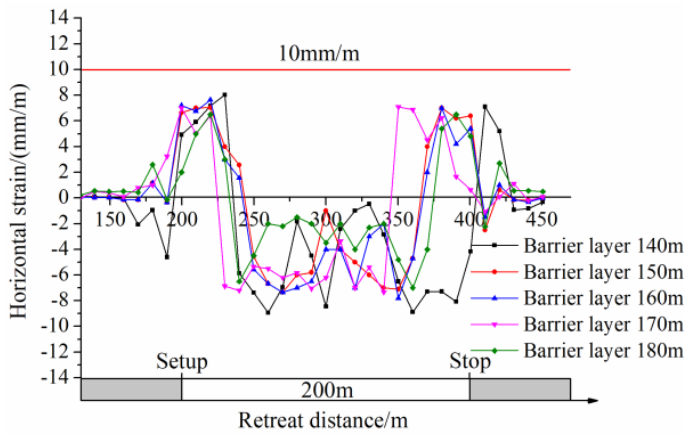

(a)

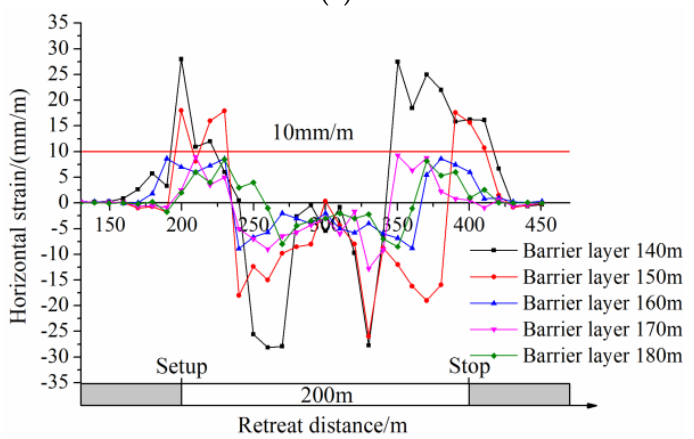

(c)

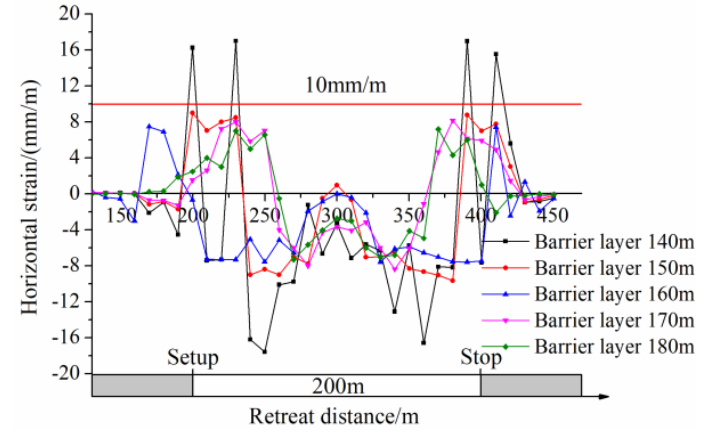

(b)

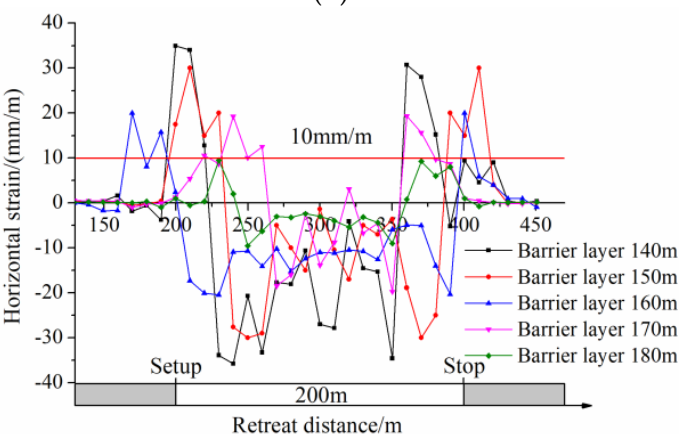

(d)

Figure 9. Cont. 


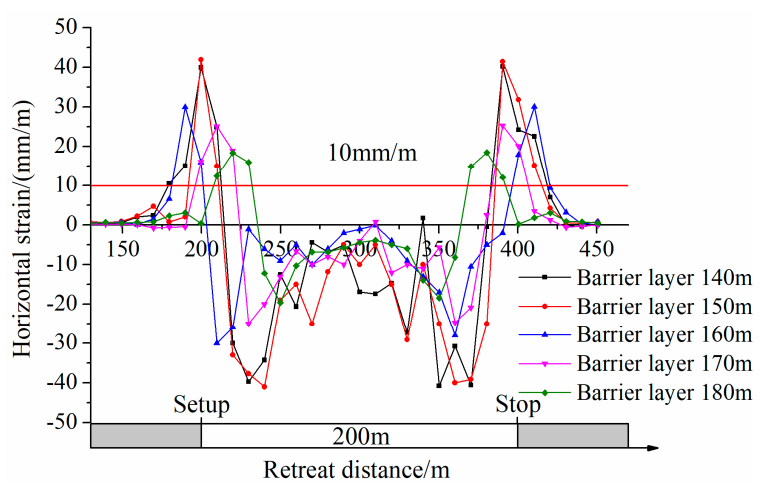

(e)

Figure 9. Horizontal strain of aquiclude with different mining heights: (a) Mining height-8 m; (b) Mining height-10 m; (c) Mining height-12 m; (d) Mining height-14 m; (e) Mining height-16 m.

The statistics associated with horizontal strains of the aquiclude with different barrier thicknesses and mining heights are summarized in Table 2. They show that, from $8 \mathrm{~m}$ to $10 \mathrm{~m}, 12 \mathrm{~m}, 12 \mathrm{~m}$ and $14 \mathrm{~m}$, critical mining height causing aquiclude destabilization gradually increases, along with an increase in barrier thickness from $140 \mathrm{~m}$ to $150 \mathrm{~m}, 160 \mathrm{~m}, 170 \mathrm{~m}$ and $180 \mathrm{~m}$.

Table 2. Summary of horizontal strains of aquiclude with different mining conditions.

\begin{tabular}{|c|c|c|c|}
\hline Thickness of Barrier Layer (m) & Mining Height (m) & Horizontal Strain $(\mathrm{mm} / \mathrm{m})$ & Critical Mining Height (m) \\
\hline \multirow{3}{*}{140} & 10 & 17 & \multirow{3}{*}{8} \\
\hline & 12 & 28 & \\
\hline & 14 & 35 & \\
\hline \multirow{4}{*}{150} & 8 & 7 & \multirow{4}{*}{10} \\
\hline & 10 & 9 & \\
\hline & 12 & 18 & \\
\hline & 14 & 39 & \\
\hline \multirow[t]{3}{*}{160} & 12 & 8.5 & \multirow[t]{3}{*}{12} \\
\hline & 14 & 20 & \\
\hline & 16 & 30 & \\
\hline \multirow{5}{*}{170} & 8 & 7 & \multirow{5}{*}{12} \\
\hline & 10 & 8 & \\
\hline & 12 & 9 & \\
\hline & 14 & 19 & \\
\hline & 16 & 25 & \\
\hline
\end{tabular}




\subsection{Roof Water Inrush Risk Zones}

In light of the above analysis results, related to the critical mining height with different conditions of barrier layer, the thickness contours of the coal seam and barrier layer are utilized to divide the whole underground area into three kinds of subareas: water inrush area, transition area and safe area. Detailed partitions of the three situations are shown in Figure 10c, which shows that most areas of working faces (21301-21305) in panel 21 are at risk of water inrush. In panel 22, some areas close to main roadway are at risk of water inrush caused by coal extraction. Only the southern part of panel 21, and western part of panel 22, can be divided into relatively safe areas.

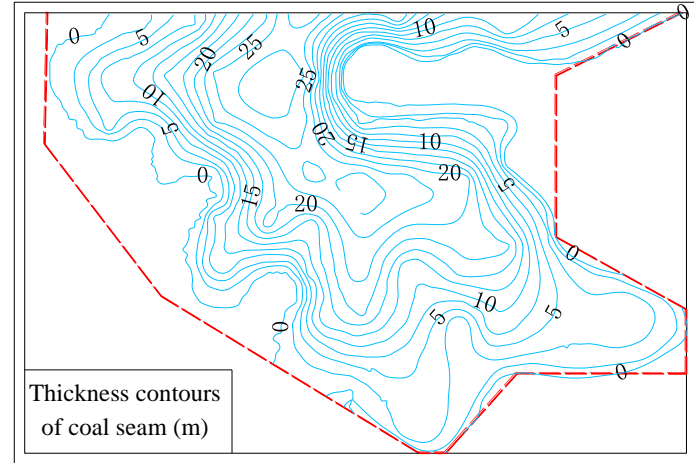

(a)

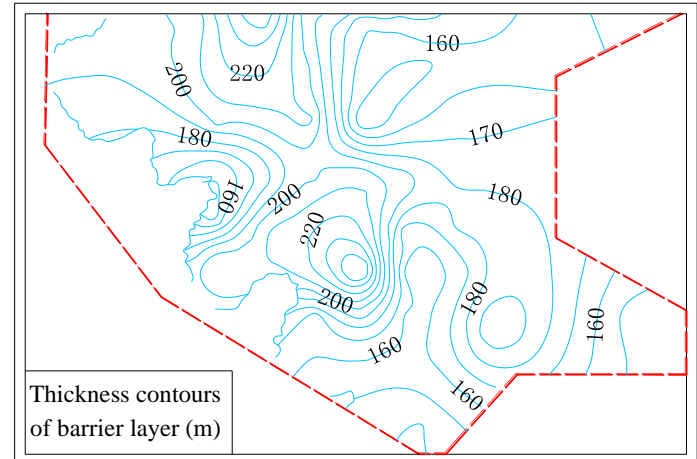

(b)

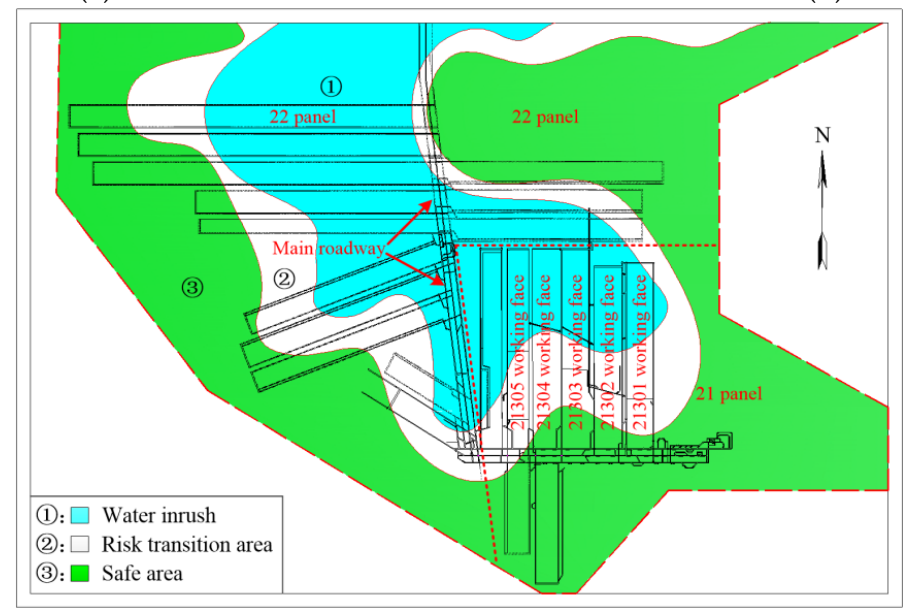

(c)

Figure 10. Thickness contours of the coal seam and barrier layer, and degrees of roof water inrush: (a) Thickness contours of coal seam; (b) Thickness contours of barrier layer; (c) Partitions with different degrees of roof water inrush.

\section{Prevention and Control Method of Mine Roof Water Inrush}

\subsection{Method to Prevent Roof Water Inrush}

The above analysis indicates that bed separation between the upper aquifer and lower aquiclude can exist and continuously expand, due to underground mining. The bed separation provides water flowing from the aquifer with storage space, and this water can flow into the deeper working face, triggering water inrush. This process may offer a good explanation for the fact that roof water inrush occurs later than water level decline in the aquifer, due to the fact that, before working face extraction, united boreholes can be drilled from both the surface and underground, to detect and discharge the water accumulated and stored in the space caused by bed separation. Based on the numerical simulation of 21301 and 21302 working faces in Cuimu coal mine, we find that bed separation always reaches its maximum in the center of overburden, along the layout direction of the working face 
(as shown in Figure 5). At the same time, the center position is often the lowest in the subsidence basin, which causes the accumulation of water in the aquifer. We suggest that the surface borehole for discharging water stored in bed separation should be arranged in the center of overburden, while the upwards borehole should be drilled into the bed separation between the upper aquifer and the aquiclude. This method may lower the risk of mine roof water inrush. An arrangement form of united boreholes is displayed in Figure 11.

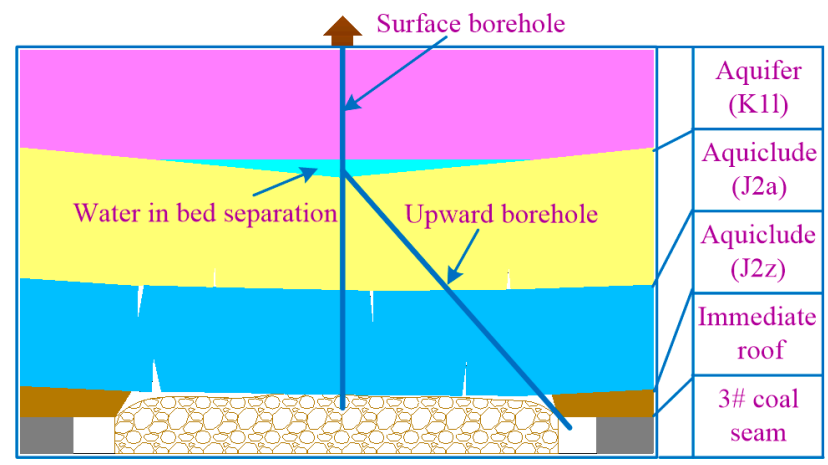

Figure 11. Sketch map of arrangement form of united boreholes.

\subsection{Field Test Validation}

The majority of 21303 panel in Cuimu coal mine is situated in a water inrush area and transition area. It has a greater tendency towards water inrush during underground coal mining. Therefore, 21303 working face was selected for the field test. Based on the concept of mine roof water inrush prevention mentioned above, a surface borehole combined with an underground borehole were simultaneously arranged for water drainage.

\subsubsection{Layout of Boreholes}

As shown in Figure 12, two vertical boreholes, including G4 and G5, were drilled from surface right, above 21303 working face. The borehole G4 was ahead of the setup room at a distance of $170 \mathrm{~m}$, compared to borehole G5, at $540 \mathrm{~m}$, and $40 \mathrm{~m}$ from the belt roadway. The surface boreholes were located in the middle of the direction of the working face retreat, consistent with the position of the maximum bed separation caused by mining. Both boreholes, with diameters between 152 and $190 \mathrm{~mm}$, passed through the maximum bed separation and ended in the top of the caved zone, so that water accumulated in the bed separation could directly flow into the gob. Simultaneously, boreholes for water drainage were drilled from the high-level drainage roadway of 21303 working face to the junction of the surface borehole and bottom of the aquifer. The high-level drainage roadway was driven along the roof of the coal seam, which was $14.25 \mathrm{~m}$ away from the track roadway. Starting $150 \mathrm{~m}$ ahead of the setup room, eighty obliquely upward boreholes with angles of $65^{\circ}$ were arranged at $50 \mathrm{~m}$ spacing, along the direction of mining. The diameter of each borehole was $75 \mathrm{~mm}$. Detailed locations of both kind of borehole are shown in Figure 12.

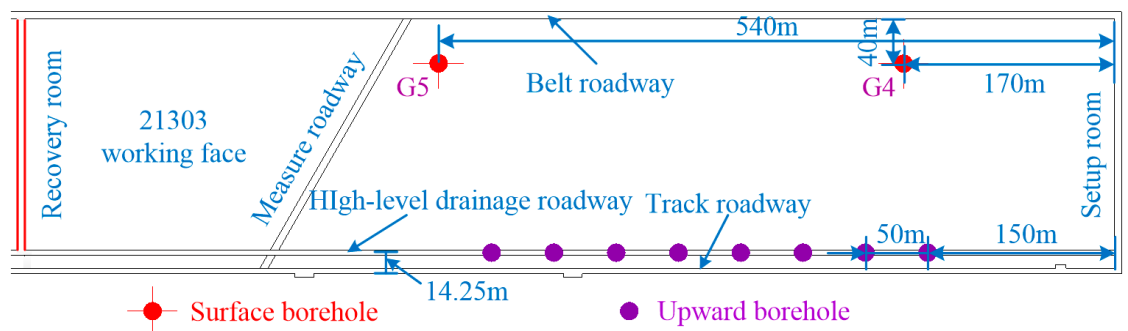

Figure 12. Layout of surface and underground boreholes for detecting and discharging water. 


\subsubsection{Test Results}

21303 working face was extracted from 22 March to 20 August. During this period, the water levels of the aquifer detected by G4 surface borehole are shown in Figure 13. The water level of the aquifer, at $1180.07 \mathrm{~m}$ on 19 March, compared to its minimum level of $983.27 \mathrm{~m}$ on 16 June, had declined by $196.8 \mathrm{~m}$ as the longwall retreated. An obvious increase in water level occurred on $1 \mathrm{July}$, because the surface borehole was blocked off, due to mining-induced strata movement. Until 16 July, the water level declined to the safety altitude, after the blocked borehole was dredged. During the whole process of 21303 retreat, the average water inflow reached $30 \mathrm{~m}^{3} / \mathrm{h}$, and there were not any roof water inrush accidents. This indicates that combining surface boreholes with underground water drainage is effective in preventing the 21303 working face from mine roof water inrush.

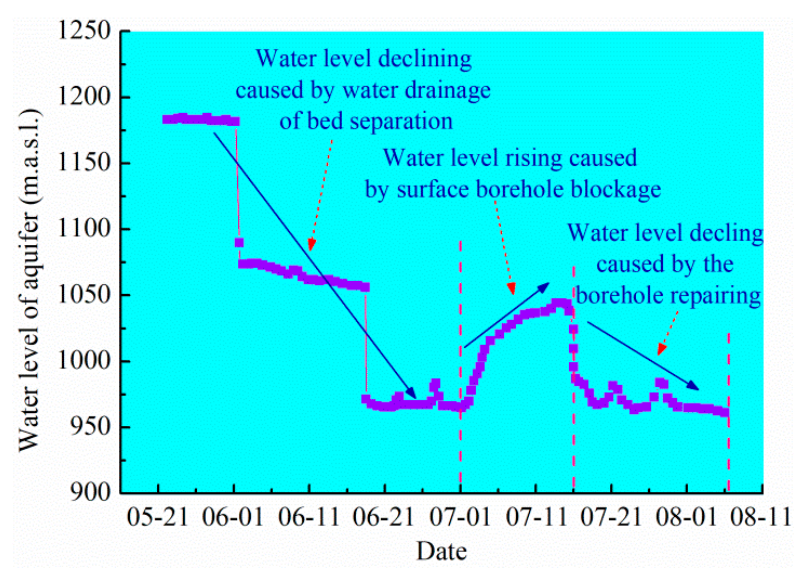

Figure 13. Water level variation of aquifer during 21303 working face mining.

\section{Conclusion}

Based on the cases of mine roof water inrush in Cuimu coal mine, this paper investigates the mechanism of mine water inrush, through analyzing the water level variation of the aquifer, as well as overlying strata movement around roof water inrush. It was found that bed separation can form between the upper aquifer and the aquiclude, and then expand to large-scale water storage space, affected by underground coal extraction. At this point, roof water inrush has not occurred, as the aquiclude has not been penetrated by mining-induced fractures. This might be the reason there is a water level decline in the aquifer, without roof water inrush. As the longwall retreat goes on, the aquiclude loses its efficacy in resisting water, after fractures penetrate the aquiclude. The amount of water originally accumulated and stored in bed separation can flow into the lower working face, to trigger mine roof water inrush. Therefore, roof water inrush in Cuimu coal mine occurs later than the water level decline in the aquifer.

Considering the relationship between water level variation, characteristics of aquiclude deformation and mine roof water inrush, tension-induced horizontal strains of aquiclude are identified as the index to evaluate the stability of aquiclude and mine roof water inrush affected by underground coal extraction. The threshold value of roof water inrush in Cuimu coal mine is a maximum horizontal strain bigger than $10 \mathrm{~mm} / \mathrm{m}$. For different coal mines, different geological conditions-such as the depth of coal seam, the characteristics of strata, the thickness of the aquiclude, and the thickness of the barrier layer-the threshold value of the maximum horizontal strain of aquiclude, to predict mine roof water inrush, may be different.

After the determination of the roof water inrush mechanism and threshold value, risk classification was conducted, to divide the whole underground area into three zones, including water inrush area, transition area and safe area. This was based on the assessment of the critical mining height at different thicknesses of barrier layer, and different heights of extraction. 
For roof water inrush management, surface vertical boreholes and underground oblique boreholes are combined, to drain the water accumulated and stored in the bed separation space before coal extraction. Field validation was conducted to verify that this method can effectively reduce the risks of roof water inrush for underground work.

Author Contributions: G.F. designed the overall concept of the study; S.Z. processed and analyzed the data and composed the paper; D.Z. adjusted the structure of the paper and modified some of the content; C.Z. modified the article structure and corrected spelling, grammar, and verb tense errors to improve the readability; M.C. completed the content of numerical simulation; Q.L. conducted the water level monitoring of aquifer on-site.

Funding: This work was financially supported by the Fundamental Research Funds for the Central Universities grant number [2017XKQY073].

Acknowledgments: The authors are grateful to the Cuimu coal mine in Shanxi for their support during the water level monitoring of aquifer on-site as well as to the helpful comments provided by anonymous reviewers.

Conflicts of Interest: The authors declare no conflict of interest.

\section{References}

1. Bukowski, P. Water hazard assessment in active shafts in upper silesian coal basin mines. Mine Water Environ. 2011, 30, 302-311. [CrossRef]

2. Gui, H.; Song, X.; Lin, M. Water-inrush mechanism research mining above karst confined aquifer and applications in North China coalmines. Arab. J. Geosci. 2017, 10, 1-9. [CrossRef]

3. Gudmundsson, A.; Berg, S.S.; Lyslo, K.B.; Skurtveit, E. Fracture networks and fluid transport in active fault zones. J. Struct. Geol. 2001, 23, 343-353. [CrossRef]

4. Babiker, M.; Gudmundsson, A. The effects of dykes and faults on groundwater flow in an arid land: The Red Sea Hills, Sudan. J. Hydrol. 2004, 297, 256-273. [CrossRef]

5. Mclellan, J.G.; Oliver, N.H.S.; Schaubs, P.M. Fluid flow in extensional environments; numerical modelling with an application to Hamersley iron ores. J. Struct. Geol. 2004, 26, 1157-1171. [CrossRef]

6. Li, L.; Yang, T.; Liang, Z.; Zhu, W.; Tang, C. Numerical investigation of groundwater outbursts near faults in underground coal mines. Int. J. Coal Geol. 2011, 85, 276-288. [CrossRef]

7. Chen, L.; Feng, X.; Xie, W.; Xu, D. Prediction of water-inrush risk areas in process of mining under the unconsolidated and confined aquifer: A case study from the Qidong coal mine in China. Environ. Earth Sci. 2016, 75, 706. [CrossRef]

8. Tahershamsi, A.; Feizi, A.; Molaei, S. Modeling groundwater surface by MODFLOW math code and geostatistical method. Civ. Eng. J. 2018, 4, 812-827. [CrossRef]

9. Zhang, S.; Fan, G.; Zhang, D.; Li, Q. Physical simulation research on evolution laws of clay aquifuge stability during slice mining. Environ. Earth Sci. 2018, 77, 1-10. [CrossRef]

10. Petrie, E.S.; Petrie, R.A.; Evans, J.P. Identification of reactivation and increased permeability associated with a fault damage zone using a multidisciplinary approach. J. Struct. Geol. 2014, 59, 37-49. [CrossRef]

11. Wiprut, D.; Zoback, M.D. Fault reactivation and fluid flow along a previously dormant normal fault in the northern North Sea. Geology 2000, 28, 595-598. [CrossRef]

12. Li, S.; Xu, F.; Zhang, Q.; Li, L.; Wang, W.; Liu, H. Analysis and construction techniques for a water seal for underground mines subjected to water inrush. Mine Water Environ. 2016, 35, 168-179. [CrossRef]

13. Ma, D.; Bai, H.; Wang, Y. Mechanical behavior of a coal seam penetrated by a karst collapse pillar: Mining-induced groundwater inrush risk. Nat. Hazards 2015, 75, 2137-2151. [CrossRef]

14. Donnelly, L.J. A review of coal mining induced fault reactivation in Great Britain. Q. J. Eng. Geol. Hydrogeol. 2006, 39, 5-50. [CrossRef]

15. Islam, M.R.; Hayashi, D.; Kamruzzaman, A.B.M. Finite element modeling of stress distributions and problems for multi-slice longwall mining in Bangladesh, with special reference to the Barapukuria coal mine. Int. J. Coal Geol. 2009, 78, 91-109. [CrossRef]

16. Zhang, R.; Jiang, Z.; Zhou, H.; Yang, C.; Xiao, S. Groundwater outbursts from faults above a confined aquifer in the coal mining. Nat. Hazards 2014, 71, 1861-1872. [CrossRef]

17. Yin, S.; Zhang, J.; Liu, D. A study of mine water inrushes by measurements of in situ stress and rock failures. Nat. Hazards 2015, 79, 1961-1979. [CrossRef] 
18. Wu, Q.; Liu, Y.; Zhou, W. Evaluation of water inrush vulnerability from aquifers overlying coal seams in the menkeqing coal mine, China. Mine Water Environ. 2015, 34, 258. [CrossRef]

19. Wang, J.A.; Park, H.D. Coal mining above a confined aquifer. Int. J. Rock Mech. Min. Sci. 2003, 40, 537-551. [CrossRef]

20. Klose, C.D. Mine water discharge and flooding: A cause of severe earthquakes. Mine Water Environ. 2007, 26, 172-180. [CrossRef]

21. Yin, H.; Zhao, H.; Xie, D.; Sang, S.; Shi, Y.; Tian, M. Mechanism of mine water inrush from overlying porous aquifer in Quaternary: A case study in Xinhe Coal Mine of Shandong Province, China. Arab. J. Geosci. 2019, 12, 1-12. [CrossRef]

22. Zhou, Q.; Herrera, J.; Hidalgo, A. The uumerical analysis of fault-induced mine water inrush using the extended finite element method and fracture mechanics. Mine Water Environ. 2018, 37, 185-195. [CrossRef]

23. Zhang, J.; Yang, T. Study of a roof water inrush prediction model in shallow seam mining based on an analytic hierarchy process using a grey relational analysis method. Arab. J. Geosci. 2018, 11, 1-12. [CrossRef]

24. Hu, Y.; Liu, W.; Ma, T.; Yang, R.; Liang, D. Analysis on the stability of the inclined water-resisting roof layer while mining under the confined aquifer. Geotech. Geol. Eng. 2019, 37, 995-1006. [CrossRef]

25. Adhikary, D.P.; Guo, H. Measurement of longwall mining induced strata permeability. Geotech. Geol. Eng. 2014, 32, 617-626. [CrossRef]

26. Booht, C.J.; Curtiss, A.M.; Demaris, P.J.; Bauer, R.A. Site-specific variation in the potentiometric response to subsidence above active longwall mining. Environ. Eng. Geosci. 2000, 6, 383-394.

27. Zhang, D.; Fan, G.; Liu, Y.; Ma, L. Field trials of aquifer protection in longwall mining of shallow coal seams in China. Int. J. Rock Mech. Min. Sci. 2010, 47, 908-914. [CrossRef]

28. Zhang, D.S.; Fan, G.W.; Ma, L.Q.; Wang, X.F. Aquifer protection during longwall mining of shallow coal seams: A case study in the Shendong Coalfield of China. Int. J. Coal Geol. 2011, 86, 190-196. [CrossRef]

29. Adams, R.; Younger, P.L. A strategy for modeling ground water rebound in abandoned deep mine systems. Ground Water 2010, 39, 249-261. [CrossRef]

30. Majdi, A.; Hassani, F.P.; Nasiri, M.Y. Prediction of the height of destressed zone above the mined panel roof in longwall coal mining. Int. J. Coal Geol. 2012, 98, 62-72. [CrossRef]

31. Dong, Q.; Cai, R.; Yang, W. Simulation of water-resistance of a clay layer during mining: Analysis of a safe water head. J. China Univ. Min. Technol. 2007, 17, 345-348. [CrossRef]

32. Xu, G.; Xu, J.; Lv, W.; Fan, D. Lateral boundary prediction of water conducting fracture formed in roof and its application. Chin. J. Geotech. Eng. 2010, 32, 724-730. [CrossRef]

33. Kong, H.; Miao, X.; Wang, L.; Zhang, Y.; Chen, Z. Analysis of the harmfulness of water-inrush from coal seam floor based on seepage instability theory. J. China Univ. Min. Technol. 2007, 17, 453-458. [CrossRef] 